\title{
MARKETING MANAGEMENT DIII STUDENTS' DISTANCE EDUCATION EFFECTIVENESS FOR CITIZENS WITH SPECIAL NEEDS
}

Maria Nino Istia, Rahma Nur Praptiwi, Kristin Lukitaningrum

Jakarta State Polytechnic, Indonesia

E-mail: maria.ninoistia@akuntansi.pnj.ac.id, rahma.nurpraptiwi@akuntansi.pnj.ac.id, kristin.lukitaningrum@mp.pnj.ac.id

\begin{tabular}{|c|c|}
\hline ARTICLE INFO & ABSTRACT \\
\hline $\begin{array}{l}\text { Received: } \\
\text { October, 26 } \\
2021 \\
\text { Revised: } \\
\text { November, 16 } \\
2021 \\
\text { Approved: } \\
\text { November, 18 } \\
2021\end{array}$ & $\begin{array}{l}\text { The existence of individuals with developmental and } \\
\text { sensory disabilities (DIII MP-WNBK students) at the } \\
\text { Jakarta State Polytechnic is a concern, especially when it is } \\
\text { observed how they interact, the way they receive and } \\
\text { attend lectures in class. So the situation that is completely } \\
\text { online like this, becomes a challenge for them. The } \\
\text { purpose of this study is to examine the effectiveness of } \\
\text { distance education for MP-WNBK DIII students, and to } \\
\text { explain efforts to improve their skills in accessing online } \\
\text { lectures through the elearning.pnj.ac.id platform. This } \\
\text { study uses an intervention method with a quantitative } \\
\text { approach. The design of this research is a cross sectional } \\
\text { study. The sample in this study was PS DIII MP-WNBK PNJ } \\
\text { students. The number of samples taken as many as } 76 \\
\text { students from a population of } 92 \text { students. The results of } \\
\text { this study conclude that both lecturers and students enjoy } \\
\text { using e-learning as a learning medium during distance } \\
\text { learning. Learning with a high level of interaction is fun for } \\
\text { both lecturers and students because it approaches face- } \\
\text { to-face learning. Almost all students are able to use e- } \\
\text { learning. E-learning is quite effective for distance learning. }\end{array}$ \\
\hline KEYWORDS & $\begin{array}{l}\text { Distance Education, Online Lectures, Citizens With Special } \\
\text { Needs }\end{array}$ \\
\hline
\end{tabular}

Maria Nino Istia, Rahma Nur Praptiwi, Kristin Lukitaningrum.

(2021). Marketing Management DIII Students' Distance Education Effectiveness for Citizens with Special Needs. Journal Eduvest.

1(11): 1287-1295

How to cite:

E-ISSN:

Published by: 


\begin{tabular}{lll}
\hline (C) (i) (2) & This work is licensed under a Creative Commons \\
Attribution-ShareAlike 4.0 International
\end{tabular}

\section{INTRODUCTION}

The Marketing Management Study Program for Citizens with Special Needs (MP-WNBK) Jakarta State Polytechnic provides diploma-level education services for citizens with special needs. The active students of the PNJ MP-WNBK Study Program are students with various disabilities, including developmental disabilities such as autism spectrum disorder (ASD) — or commonly known as autism, attention deficit hyperactivity disorder (ADHD) - or commonly called hyperactivity, cerebral palsy ( paralysis of the cerebrum so that they have problems with body movements and postures), Down syndrome (physical, mental disorders, and have a low level of intelligence), slow learner (slow learning), dyslexia and dyscalculia (disorders in the development of reading, writing and arithmetic); and sensory impairments in hearing (deafness), as well as in vision (low vision).

The Covid-19 pandemic has had a significant impact on various aspects of daily life (Puspitasari, 2020). One of them is the field of education. Teaching and learning activities cannot be carried out face-to-face on campus. Thus forcing students and educators to adapt to online learning methods (Ulfa, 2021) (Jamaluddin, Ratnasih, Gunawan, \& Paujiah, 2020). Socialization activities and training on the use of e-learning have been carried out. However, along with the implementation of online distance education through the e-learning.pnj.ac.id application, obstacles were found (Fikri et al., 2021). Based on this, researchers are motivated to develop skills in the use of e-learning as an effort to improve educational services for students of the MP-WNBK PNJ DIII Study Program. Through this research, it is hoped that obstacles or obstacles for them and their lecturers can be found and overcome. In this regard, it is also hoped that this will have an impact on increasing learning motivation and fostering the confidence of the DIII MP-WNBK PNJ Study Program students in carrying out PJJ during the pandemic. This study has the following objectives:

1. Knowing the attitudes of lecturers and students in carrying out PJJ

2. Knowing the ability of students to use e-learning facilities

3. Knowing the effectiveness of using e-learning for PS DIII MP-WNBK PNJ students

People with disabilities are people who have specific characteristics and are different from people in general (Aulia, Asiah, \& Irfan, 2020; Maftuhin, 2016). These special characteristics require special services in order to obtain their rights as human beings (Luthfia, 2020). People with special needs have a very broad definition, including people who have physical disabilities, low IQ (Intelligence Quotient) abilities, and people with very complex problems, so that their cognitive functions are impaired (Radissa et al., 2020). According to WHO, disability is an inability to carry out certain activities like normal people, which is caused by conditions of loss or inability both psychologically, physiologically or anatomically structural or functional abnormalities (United Nations, 2020). Disabilities are the inability to carry out certain activities like normal people caused by impairment conditions (loss or inability) related to age and society (SYAFITRI, 2019) (Hidayatullah \& Pranowo, 2018). Insights about non-physical disabilities that have not been comprehensive in the wider community have resulted in unconsciousness or wrong views of persons/individuals with non-physical disabilities (Yazfinedi, 2018) (Tighe \& Schatschneider, 2016). 
It is often found that persons with disabilities are seen as persons with physical disabilities only. Whereas the term disability also includes non-physical disabilities. In (Law of the Republic of Indonesia, 2016) concerning Persons with Disabilities, in Chapter 1 Article 1 , it is stated that persons with disabilities are any person who experiences physical, intellectual, mental, and/or sensory limitations for a long period of time in interacting with the environment. may experience barriers and difficulties to participate fully and effectively with other citizens on the basis of equal rights.

The outbreak of Covid-19 in all regions has an impact on various aspects of people's lives, including the education aspect (Sari, Rifki, \& Karmila, 2020). Where education is carried out remotely online / online. The Covid-19 pandemic has not only had an impact on the ordinary education system for students in general, but it has also affected the education system for individuals with special needs. This condition raises its own obstacles and challenges for individual educators with special needs in implementing Distance Education. The same is true for students with special needs. It is necessary to integrate technology and innovation in the implementation of PJJ in order to provide meaningful learning activities (Sandi, 2020).

According to (Abidin, Hudaya, \& Anjani, 2020) a learning is said to be effective if it meets the main requirements for teaching effectiveness, namely:

a. A high percentage of student learning time is devoted to KBM;

b. High average of task performing behavior among students;

c. The stipulation between the content of the teaching material and the student's ability (learning success orientation) is prioritized; and

d. Develop a friendly and positive learning atmosphere, develop a class structure that supports item $b$, without ignoring item $d$

The limited ability to operate applications that support online learning, of course, requires tools for them to adapt and familiarize themselves. Distance learning aids can be in the form of handbooks operating the platforms used, such as elearning.pnj.ac.id, email, zoom, Google Meet, and whatsapp. Not only students and lecturers, but also many parents of students who have difficulties in accessing the online media above.

Knowledge of the characteristics and handling of individuals with developmental disabilities is still needed in the general public, including institutions and study programs, especially in terms of running the distance education system. Until now, the involvement, collaboration, and communication built by parents/families, students, and lecturers are one of the ways that are still applied in the implementation of Distance Learning.

\section{RESEARCH METHOD}

This study uses an intervention method with a quantitative approach. The design of this research is a cross sectional study. Cross sectional study is data collected at a certain time to provide an overview of the development of the situation at that time. The research was conducted at the DIII Marketing Management Study Program for Citizens with Special Needs at the Jakarta State Polytechnic (PS DIII MP-WNBK PNJ). The sample in this study was PS DIII MP-WNBK PNJ students. The number of samples taken as many as 76 students from a population of 92 students. Data collection was carried out from June to September 2021.

Primary data was obtained by using a questionnaire while secondary data was obtained by field observation. Data processing is carried out using a computer program Microsoft Excel 2016 for windows. The stages of data processing carried out in this study include: 
1. Editing, coding, scoring, and entry

2. After the data is entered, then data cleaning is carried out to ensure there are no errors in entering the data. Descriptive analysis and cross tabulation.

\section{RESULT AND DISCUSSION}

Respondents in this study were students of the Marketing Management Study Program for Citizens with Special Needs, Jakarta State Polytechnic. The following are the characteristics of respondents by semester

Table 1 Characteristics of Respondents by Semester

\begin{tabular}{cll}
\hline Student Semester & $\mathrm{N}$ & $\%$ \\
\hline 1 & 18 & 23.68 \\
\hline 3 & 25 & 32.89 \\
\hline 5 & 17 & 22.37 \\
\hline 6 & 17 & 22.37 \\
\hline
\end{tabular}

Based on Table 1, it can be concluded that the respondents are almost evenly distributed from each semester, but the most participating in this study are semester 3 students. Semester 1 students are new students or students who enter the 2021/2022 academic year. Meanwhile, semester 6 students are students who enter the 2018/2019 academic year who are currently carrying out their Final Project.

Table 2 Characteristics of Respondents Based on the Type of Internet Network Used.

\begin{tabular}{lll}
\hline Network Type & $\mathrm{N}$ & $\%$ \\
\hline WIFI & 68 & 89.47 \\
\hline Data pack & 8 & 10.53 \\
\hline
\end{tabular}

Based on Table 2, it can be concluded that most $(89.47 \%)$ respondents use WIFI networks. Only a small proportion $(10.53 \%)$ use data packages. Based on the results of observations, some of the users of data packets have an unstable network and often have problems.

Table 3 Ease of Respondents Internet Access

\begin{tabular}{cll}
\hline Ease of Access & $\mathrm{N}$ & $\%$ \\
\hline Yes & 73 & 96.05 \\
\hline No & 3 & 3.95 \\
\hline
\end{tabular}

Based on Table 3, it can be concluded that almost all (96.05\%) respondents find it easy to access the internet. Based on observations, respondents who have difficulty accessing the internet are often constrained due to problematic internet networks.

Table 4 Respondents who Like to Learn with E-Learning

\begin{tabular}{cll}
\hline $\begin{array}{l}\text { Loving learning with E- } \\
\text { Learning }\end{array}$ & $\mathrm{N}$ & $\%$ \\
\hline Yes & 68 & 89.47 \\
\hline No & 8 & 10.53 \\
\hline
\end{tabular}

Based on Table 4, it can be concluded that the majority (89.47\%) of respondents like learning with e-learning. Learning with e-learning makes it easy for us to find materials, collect assignments, fill out attendance lists on the same page. A small proportion $(10.53 \%)$ of respondents do not like learning with e-learning. For them, learning with e-learning is less able to interact with friends and lecturers. Respondents 
who are satisfied with distance learning currently think that lecturers really try to provide convenience in carrying out distance learning and as much as possible minimize the obstacles that cause students to feel burdened by distance learning. Meanwhile, respondents who were dissatisfied thought that some lecturers seemed careless in carrying out distance learning, this can be seen from the results of interviews with respondents who explained that a small number of lecturers gave more assignments and did not explain via Google Meet or Zoom.

\begin{tabular}{|c|c|c|c|}
\hline $\begin{array}{l}\text { E-Learning } \\
\text { Learning Easy }\end{array}$ & Makes & $\mathrm{N}$ & $\%$ \\
\hline Yes & & 70 & 92.11 \\
\hline No & & 6 & 7.89 \\
\hline
\end{tabular}

Table 5 explains that almost all $(92.11 \%)$ respondents feel that e-learning makes learning easier. Before using e-learning, PS DIII MP-WNBK PNJ used WhatsApp for 1 semester and used Google Classroom for 1 semester. Compared to using Whatsapp media, respondents find it easier to learn with e-learning. Respondents also stated that most of the lecturers tried to interact with students such as the opportunity to ask questions related to learning materials. Students are also given the opportunity to give their opinion.

Table 6 Respondents Feel No Barriers in Using E-Learning

\begin{tabular}{cll}
\hline Has no barriers & $\mathrm{N}$ & $\%$ \\
\hline Yes & 63 & 82.90 \\
\hline No & 13 & 17.10 \\
\hline
\end{tabular}

Based on Table 6, the majority (82.90\%) of respondents felt that they had no obstacles in using e-learning. But it turns out that there are still a small number (17.10\%) who still have difficulty using e-learning. The data that there are still students who have obstacles in the use of e-learning will be followed up further. It is hoped that in the future, all students will not have obstacles in the use of e-learning.

Table 7 Understanding Material Theory

\begin{tabular}{cll}
\hline $\begin{array}{c}\text { Understanding Material } \\
\text { Theory }\end{array}$ & $\mathrm{N}$ & $\%$ \\
\hline Yes & 69 & 90.79 \\
\hline No & 7 & 9.21 \\
\hline
\end{tabular}

Based on Table 7, almost all $(90.79 \%)$ respondents understand the theoretical material. There is still a small percentage $(9.21 \%)$ who feel they do not understand the theoretical material. After being traced, it is suspected that this is due to limited media because students are deaf or the preference of students who prefer to study in practice. There was a reason that it was easier for them to understand learning material through distance from home, because when they did the distance learning process, generally they would be accompanied by their parents, and if there was learning material that they did not understand they would ask their parents, so respondents felt better understand the material and become closer to parents.

Table 8 Understanding Practical Materials

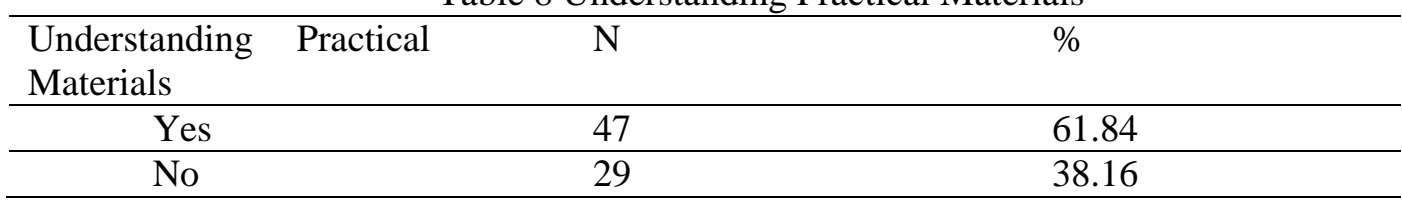


Table 8 states, more than half $(61.84 \%)$ of respondents claimed to understand practical courses using e-learning assisted by Google Meet. But almost half $(38.16 \%)$ admitted that they did not understand the practical material. Practical material is indeed more difficult to do remotely. The limited availability of tools and materials in the delivery of materials is a challenge in itself. The advantage of distance learning for practical courses is that the learning videos can be played over and over again so that if a student is left behind, the material can be replayed until the student understands the material.

Table 9 Respondents Ability to Use E-Learning

\begin{tabular}{|c|c|c|c|c|c|c|}
\hline \multirow{5}{*}{$\begin{array}{l}\text { Student } \\
\text { Answers }\end{array}$} & \multirow{5}{*}{$\begin{array}{l}\text { Can } \\
\text { Login e- } \\
\text { learning }\end{array}$} & \multirow{5}{*}{$\begin{array}{l}\text { Can Fill } \\
\text { Absence }\end{array}$} & \multirow{3}{*}{$\begin{array}{l}\text { Can Do } \\
\text { Assignments } \\
\text { by }\end{array}$} & \multirow{3}{*}{$\begin{array}{l}\text { Can } \\
\text { Assignments }\end{array}$} & \multicolumn{2}{|l|}{ Can } \\
\hline & & & & & Open & \\
\hline & & & & & Links in & Can \\
\hline & & & Uploading & with Online & & Download \\
\hline & & & Files & Text & learning & Mater \\
\hline Yes & 90.79 & 96.05 & 90.79 & 86.84 & 93.42 & 93.42 \\
\hline No & 9.21 & 3.95 & 9.21 & 13.16 & 6.58 & 6.58 \\
\hline
\end{tabular}

Based on table 9, it can be concluded that almost all respondents can use elearning facilities well. Respondents claimed to be able to log in e-learning independently (90.79\%), filling out student attendance lists independently (96.05\%), doing assignments using the file upload method independently (90.79\%), doing assignments using online text independently (86.84\%), open links to both materials and Google Meet in e-learning independently (93.42\%), and able to download materials independently (93.42\%). However, there are still a small number of respondents who still need assistance from a mentor or even a lecturer to use e-learning.

\section{Discussion}

Based on the results of the survey and observations made, both lecturers and students felt that the distance learning process using e-learning was helped. At the beginning of the pandemic, the system was not ready, so the majority of lecturers at PS DIII MP-WNBK PNJ used Whatsapp as a distance learning medium. This poses a challenge because the material becomes difficult to find because there are too many discussions in the WhatsApp group. In addition, the task was difficult to recap by the lecturer because the assignment was sent via personal chat or via email. Because the lecturer teaches more than 1 class, so it becomes a challenge in recapitulating it.

\section{Love Learning with E-Learning}

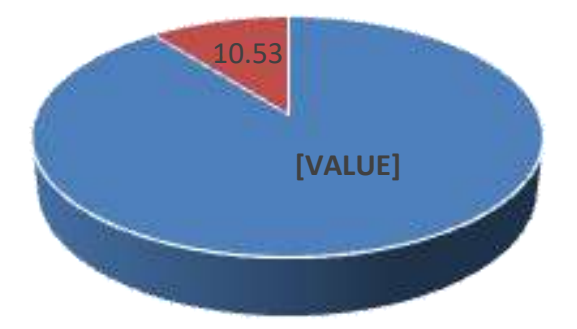

Figure 1. Respondents' Opinions on Learning to Use E-Learning 
In the odd semester of the 2020/2021 Academic Year, learning switches to using Google Classroom media. Before starting with the use of Google Classroom, both lecturers and students were given training in its use. Based on observations, almost all lecturers do not have significant obstacles in using Google Classroom. As for students, some students are still given assistance and direction by their parents, assistants, and lecturers.

In the even semester of the 2020/2021 Academic Year, distance learning is required to use e-learning for the entire PNJ academic community. As in odd semesters, before the semester starts, both lecturers and students are given e-learning training. The functions of Google Classroom and E-Learning are more or less similar. But indeed ELearning is more complex even when viewed from the user interface, Google Classroom is simpler. Currently, there are many guides for using E-Learning on Youtube, so they are quite helpful. But based on observations, some lecturers are still confused about its use, especially for setting up at the beginning of the class including enrolling students.

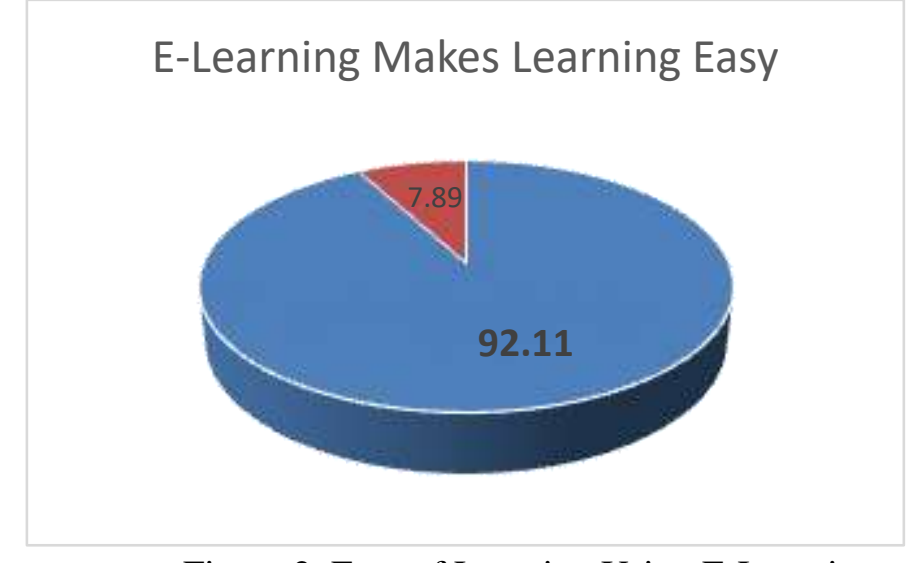

Figure 2. Ease of Learning Using E-Learning

Based on Figure 2. Almost all respondents (92.11\%) feel that the use of ELearning makes learning easier. The use of E-Learning does indeed answer the problems applied in the previous system, namely using Whatsapp and Google Classroom. The downside of using Whatsapp is disorganized material. If students want to repeat the lesson, they have to re-listen to the discussion in the group. While the group is often also used as a delivery of other information and discussion of other subjects. From the lecturer's perspective, it is difficult to recap assignments because they collect them through personal chat or even email. From the administrative side, it is difficult to recap the attendance of lecturers who at that time used Google Forms. Using Google Classroom answers some of the previous problems. Through Google Classroom, materials, assessments are organized. For attendance, both lecturers and students use Google Forms.

Based on information from a survey with open-ended questions, the obstacle in using e-learning is an unstable internet network, both using WIFI and data packages. Indeed, in its implementation, several times the server was reported to have problems. Although immediately repaired by the unit in charge. Apart from network problems they are constrained when it comes to collecting assignments. Some people still find it difficult to collect assignments in e-learning. Constraints found include files that are too large so they need to be adjusted first and difficulty doing online text assignments.

Students generally feel effective and enjoy learning using e-learning. This result is contrary to research (Aisah et al., 2021) which states that distance learning is not effective enough. Although it is considered effective, it's just that students prefer interactive learning. The use of Zoom and Google Meet to explain material, discuss, and 
other interactions is a solution so that distance learning is fun for students. Students do not like it if the lecturer only embeds material in e-learning without a qualified explanation. Students also miss close interactions full of laughter like in face-to-face lectures.

\section{CONCLUSION}

The results of this study conclude that both lecturers and students enjoy using elearning as a learning medium during distance learning. Learning with a high level of interaction is fun for both lecturers and students because it approaches face-to-face learning. Almost all students are able to use e-learning. E-learning is quite effective for distance learning.

\section{REFERENCES}

Abidin, Zainal, Hudaya, Adeng, \& Anjani, Dinda. (2020). Efektivitas Pembelajaran Jarak Jauh Pada Masa Pandemi Covid-19. Research And Development Journal Of Education, 1(1), 131. Https://Doi.Org/10.30998/Rdje.V1i1.7659

Aulia, Fara Dhania Aulia Dhania, Asiah, Dessy Hasanah Siti, \& Irfan, Maulana. (2020). Peran Pemerintah Dalam Penanganan Dampak Pandemi Covid-19 Bagi Penyandang Disabilitas. Jurnal Penelitian Dan Pengabdian Kepada Masyarakat (Jppm), 1(1), 31-41.

Fikri, Muhammad, Faizah, Nadiyatul, Elian, Sefti Adelia, Rahmani, Rena, Ananda, Muhammad Zaki, \& Suryanda, Ade. (2021). Kendala Dalam Pembelajaran Jarak Jauh Di Masa Pandemi Covid-19: Sebuah Kajian Kritis. Jurnal Education And Development, 9(1), 145.

Hidayatullah, Nururrochman, \& Pranowo. (2018). Providing More Hope And Welfare For Persons With Disabilities. Jurnal Pks, 17(2), 195-206.

Jamaluddin, Dindin, Ratnasih, Teti, Gunawan, Heri, \& Paujiah, Epa. (2020). Pembelajaran Daring Masa Pandemik Covid-19 Pada Calon Guru: Hambatan, Solusi Dan Proyeksi. $L p 2 m$.

Luthfia, Agusniar Rizka. (2020). Urgensi Pemberdayaan Penyandang Disabilitas Di Masa Pandemi. Kebijakan: Jurnal Ilmu Administrasi, 11(2), 38-44.

Maftuhin, Arif. (2016). Mengikat Makna Diskriminasi: Penyandang Cacat, Difabel, Dan Penyandang Disabilitas. Inklusi: Journal Of Disability Studies, 3(2), 139-162.

Puspitasari, Nimas. (2020). Analisis Proses Pembelajaran Dalam Jaringan Masa Pandemi Covid 19 Pada Guru Sd Negeri Dukuhwaru 01. Magistra: Media Pengembangan Ilmu Pendidikan Dasar Dan Keislaman, 11(2).

Radissa, Vanaja Syifa, Wibowo, Hery, Humaedi, Sahadi, \& Irfan, Maulana. (2020). Pemenuhan Kebutuhan Dasar Penyandang Disabilitas Pada Masa Pandemi Covid-19. Focus: Jurnal Pekerjaan Sosial, 3(1), 61-69.

Sandi, Elisabeth Diandra. (2020). 3 Strategi Atasi Tantangan Pjj Anak Berkebutuhan Khusus.

Sari, Widya, Rifki, Andi Muhammad, \& Karmila, Mila. (2020). Analisis Kebijakan Pendidikan Terkait Implementasi Pembelajaran Jarak Jauh Pada Masa Darurat Covid 19. 
Syafitri, Sekar A. Y. U. (2019). Pemenuhan Standar Pelayanan Minimal Bagi Penyandang Disabilitas Pada Layanan Transjakarta. Universitas Yarsi.

Tighe, Elizabeth L., \& Schatschneider, Christopher. (2016). Examining The Relationships Of Component Reading Skills To Reading Comprehension In Struggling Adult Readers: A Meta-Analysis. Journal Of Learning Disabilities, 49(4), 395-409. Https://Doi.Org/10.1177/0022219414555415

Ulfa, Andi Yurni. (2021). Dampak Pembelajaran Daring Masa Pandemi Covid-19 (Studi Kasus Pada Orang Tua Peserta Didik): Andi Yurni Ulfa, Haerul Mutiah. Jurnal Pendidikan Sang Surya, 1(1), 22-30.

Undang-Undang Republik Indonesia. (2016). Penyandang Disabilitas. UndangUndang Republik Indonesia No.8. Https://Doi.Org/10.1109/Ciced.2018.8592188

United Nations. (2020). Policy Brief: A Disability-Inclusive Response To Covid19. Retrieved From Https://Www.Un.Org/Development/Desa/Disabilities/WpContent/Uploads/Sites/15/2020/05/Sg_Policy_Brief_On_Persons_With_Disa bilities_Final.Pdf

Yazfinedi. (2018). Konsep, Permasalahan, Dan Solusi Penyandang Disabilitas Mental Di Indonesia. Jurnal Ilmiah Kesejahteraan Sosial, Xiv(26), 101-110. 